\title{
Chapter 8 \\ Devolution and Local Development in Emerging States: The Case of Kenya
}

\author{
Tomoya Matsumoto
}

\subsection{Introduction}

It is often the case that top-down approaches for public policy decisions by the central government for local development do not satisfy local needs because of differences in local preference and endowment, combined with the limited knowledge of central planners about local needs (Easterly 2008). Also, due to multiple administrative layers and low motivation of public officers, implementation of such policies is inefficient in their delivery and unsatisfactory in quality and often ends up wasting resources. Moreover, public funds are often used by leaders to attract political support from local residents in exchange for public investment in their locality. This tendency has been observed by some existing studies in countries with a powerful authoritarian government and poorly educated citizens (Hodler and Raschky 2014).

It seems natural for local residents to demand devolution, which brings political decision-making and funds for public services closer to residents in a country with multiple groups of people with different interests. Moreover, devolution movements are often seen more in emerging economies where regional gaps are expanding and more people are politically enlightened and raising their voices. Consequently, local residents and firms demand improvement of public services more aggressively in emerging countries than in poorer countries (Bahl and Ichimura 2008).

In Kenya, the president had been having strong political influence in public resource allocation since its independence (Burgess et al. 2015; Briggs 2014). Since the 1992 election, the multiparty political system has been embraced in this country, and the president's influence has weakened, at least in the case of allocation of road infrastructure investment funds (Burgess et al. 2015). There have also been two significant changes, toward devolution, in Kenyan politics in the last two decades. First, Kenya established the Constituency Development Fund (CDF) in 2003, which is an

T. Matsumoto $(\varangle)$

Otaru University of Commerce, 3-5-21 Midori, Otaru 047-8501, Japan

e-mail: tmatsumoto@res.otaru-uc.ac.jp

(C) The Author(s) 2019

Y. Takagi et al. (eds.), Developmental State Building, Emerging-Economy State and International Policy Studies, https://doi.org/10.1007/978-981-13-2904-3_8 
annual budgetary allocation by the central government to each of the constituencies of the Members of Parliament (MP) and whose distribution is exclusively rule-based, so that political powers would not distort the allocation. Whereas the CDF is an innovative tool to bring funds and their expenditure decisions to people at the grassroots level to maximize their welfare, there are also concerns regarding the utilization of the funds because the constituencies largely vary in physical or geographic characteristics, as well as the degree of residents' solidarity and capacity (Kimenyi 2005). We do not know much about its welfare impact since there is no study that systematically examines the bottom-up policies, planned and implemented by different localities, although there are several case studies targeting a specific constituency to examine the role of the CDF projects and their consequences (Auya and Oino 2013; Simiyu et al. 2014; Katamei et al. 2015; Ngiri and Nyaribo 2016).

Second, a new constitution, promulgated in 2010, aimed at division of political power and established a system of devolved government with 47 lower-level county governments. For the implementation, the 47 new county governors were elected in 2013 and became responsible for the provision of some public services, such as pre-primary education, healthcare service delivery, and local road infrastructure. At the same time, county governments gained the right to collect some types of taxes by themselves, such as property and entertainment taxes as county revenue, in addition to the equitable share allocated by the national government. County governments have enhanced discretion to utilize public funds for their local residents. Its impact on subnational economic performance has not been systematically analyzed.

With devolution in Kenya, the question arises as to which change enhances local economic development and improves the use of public funds by local authorities. Because of the paucity of accurate measurements of economic performance at the subnational level, it has been difficult to examine the effect of political and financial devolution on regional economic development and consequently no study addresses this issue.

Nonetheless, progress of remote sensing techniques, in the last decade, using image information from outer space via satellites enables us to accurately measure an indicator that represents subnational economic activities. Since seminal works (Henderson et al. 2012; Chen and Nordhaus 2011; Doll et al. 2006) show high correlation between nighttime light intensities, extracted from satellite images of earth, and the GDP of corresponding regions or countries, more and more studies have been using satellite nighttime light images to analyze various socioeconomic issues with subnational economic indicators (Amavilah 2017; Alesina et al. 2016; Asher and Novosad 2017; Mellander et al. 2015; Hodler and Raschky 2014).

Given the availability of a long-term (1992-2016) subnational economic performance indicator based on nighttime light intensity, Kenya provides a unique quasiexperimental environment to make a comparison in economic performance across regions, before and after a political system change and/or a change in leadership. To our best knowledge, there are no rigorous empirical studies on local development examining its determinants during the devolution era of an emerging state in Africa. This chapter is an attempt to fill the gap. 
Using satellite image information on nighttime light intensity as a measurement of subnational economic performance, we investigate factors affecting the economic development at the subnational level in Kenya from 1992 to 2016. We find that (i) ethnicities of counties are not correlated with their average annual growth rate of nighttime light intensity from 1992 to 2012 . However, (ii) during the recent 5-year period from 2012 to 2016 that largely overlapped with the ruling period of President Uhuru Kenyatta, whose ethnicity is Kikuyu, the Kikuyu dominant counties, which have more than a 50\% share of the Kikuyu population, show much higher growth rates of nighttime light intensity than other counties; (iii) county governors' characteristics, such as their educational attainment or experiences as a member of parliament, are not associated with the county growth rates; (iv) proportions of secondary school graduates and urban population of counties are positively associated with the county growth rate of nighttime light intensity.

The remainder of this chapter is organized as follows. Section 8.2 briefly describes the background of Kenyan politics since its independence and the current devolution process. The data used in this chapter and their descriptive statistics are presented in Sect. 8.3. Section 8.4 presents the empirical strategies and the regression results. Section 8.5 interprets and discusses the empirical findings, followed by the conclusion in Sect. 8.6.

\subsection{Kenya's Political Background}

Kenya has experienced significant political system reforms from a highly centralized autocracy to a decentralized democracy. The national assembly and presidential elections under the multiparty system were first held in 1992, responding to local and foreign pressures to introduce democracy. Until then, the government of Kenya was organized under the one-party system and the president had monopolized the authority of personnel matters to hire and dismiss government administrators, as well as cabinet ministers, and hence, exerted a tremendous influence on the allocation of public resources (Burgess et al. 2015). During the last 15 years since Mwai Kibaki won the presidential election in 2002, after the 24-year rule of Daniel Arap Moi, significant policy reforms toward decentralization have been implemented.

First, the Constituency Development Fund (CDF) was established through the Constituency Development Fund Act of 2003, which is an annual budgetary allocation by the central government to each of the constituencies of the Members of Parliament (MP) and whose distribution is exclusively rule-based, so that political powers would not distort the allocation. Moreover, utilization of the fund is largely at the discretion of the constituents, although there are some restrictions in its use to ensure transparency and accountability (Kimenyi 2005). The CDF is a devolved fund involving redistribution of resources and authority through legislation, although it currently accounts for only $2.5 \%$ of the national government budget.

Second, the new constitution was promulgated in 2010 and altered the division of political power and established a system of a devolved government and 47 lower- 
level county governments. The new president and 47 new county governors were elected under the new constitution in March 2013. The county governments became responsible for the provision of certain types of public services, such as pre-primary education, health service delivery, and the construction and maintenance of local roads on behalf of the national government. At the same time, counties had rights to impose several types of taxes, such as property and entertainment taxes to earn their revenue, in addition to the equitable share allocated by the national government. Kenya's Commission on Revenue Allocation (CRA) recommends to the National Assembly the basis for equitable division of the revenue of the national government among the county governments, as well as the amount of money that each county government receives. Currently, $15 \%$ of the national government revenue is allocated as the equitable share. Since the political system reform, the county governments have had enhanced discretion to utilize public funds for their local residents through the devolution movement. Thus, it is expected that the decentralized system enhances the role of local leaders and also strengthens the influence of local residents on regional development.

\subsection{Data}

We examine economic performance indicators at the subnational level and their relationships with ethnic composition, population size of the regions, and local political leaders' and residents' characteristics to see the influence of those factors on local economic development. Table 8.1 shows summary statistics of the variables used in the analyses. The sources and constructions are described in the following subsections.

\subsubsection{Nighttime Luminosity}

We need longitudinal subnational-level indicators, representing economic performance of each area, to examine the difference in economic development across areas within a country. As the unit of subnational area of Kenya, we choose counties that are new administrative units, envisioned by the 2010 Constitution of Kenya and organized by the general election in 2013 as the units of devolved government. There are 47 counties whose boundaries are based on the legal districts as on 1992. We utilize satellite image data on nighttime luminosity and construct the nighttime light intensity, by county, to represent economic performance of the area from 1992 to 2016, based on areas surrounded by the current county borders as the county units.

The nighttime luminosity has been increasingly used by researchers who need subnational economic performance data, in particular, for developing countries like Sub-Saharan African countries where there are no accurate economic performance data at the subnational level (Jerven 2013). 
Table 8.1 Summary statistics

\begin{tabular}{|c|c|c|}
\hline \multirow[t]{2}{*}{ Variables } & $(1)$ & $(2)$ \\
\hline & Mean & Std. dev. \\
\hline \multicolumn{3}{|l|}{ Annual growth rate of nighttime light intensity } \\
\hline From 1992 to 2016 & 0.030 & 0.015 \\
\hline From 1992 to 2002 & 0.014 & 0.044 \\
\hline From 2002 to 2012 & 0.053 & 0.032 \\
\hline From 2012 to 2016 & 0.016 & 0.025 \\
\hline Ethnic diversity ( 1 - Herfindahl index) & 0.299 & 0.220 \\
\hline \multicolumn{3}{|l|}{ Major ethnicity dummy } \\
\hline 1 if Kikuyu county & 0.149 & 0.360 \\
\hline 1 if Kalenjin county & 0.149 & 0.360 \\
\hline 1 if Kamba county & 0.064 & 0.247 \\
\hline 1 if Luhya county & 0.085 & 0.282 \\
\hline 1 if Luo county & 0.085 & 0.282 \\
\hline \multicolumn{3}{|l|}{ Annual growth rate of population size } \\
\hline From 1990 to 2015 & 0.029 & 0.013 \\
\hline From 1990 to 2000 & 0.027 & 0.009 \\
\hline From 2000 to 2010 & 0.031 & 0.016 \\
\hline From 2010 to 2015 & 0.015 & 0.008 \\
\hline \multicolumn{3}{|c|}{ Characteristics of county residents from 2009 census } \\
\hline Proportion of urban residents & 0.258 & 0.203 \\
\hline Proportion of university graduates & 0.010 & 0.011 \\
\hline $\begin{array}{l}\text { Proportion of residents with tertiary level } \\
\text { education }\end{array}$ & 0.036 & 0.029 \\
\hline $\begin{array}{l}\text { Proportion of residents with secondary } \\
\text { level education }\end{array}$ & 0.188 & 0.098 \\
\hline \multicolumn{3}{|c|}{ Characteristics of county governors elected in the 2013 election } \\
\hline Years of experience as a MP & 1.851 & 3.323 \\
\hline Age of the county governor & 47.725 & 8.426 \\
\hline 1 if the county governor has a Ph.D. & 0.128 & 0.337 \\
\hline Observations & 47 & \\
\hline
\end{tabular}

Following existing studies (Alesina et al. 2016; Asher and Novosad 2017), we use satellite image data on nighttime light as a proxy for subnational economic performance. We use the geo-referenced nighttime luminosity images processed by NASA, the National Oceanic and Atmospheric Administration (NOAA), and the Department of Defense of the U.S. More precisely, we use (i) data from 1992, 2002, and 2012 of Version 4 DMSP-OLS Nighttime Lights Time Series, which compile annual 
average luminosity of cloud-free nighttime light ${ }^{1}$ and (ii) the nighttime light luminosity images, which are similar but more recent, provided by the Suomi National Polar-orbiting Partnership (NPP) satellite, equipped with the Visible Infrared Imaging Radiometer Suite (VIIRS), a new sensor that collects imagery and radiometric measurements with a higher resolution of both spatial units and lighting levels than the satellites used to construct Version 4 DMSP-OLS Nighttime Lights Time Series. We used the processed, cloud-free, and moonlight-free data for year 2012 and 2016, released by NASA scientists. ${ }^{2}$

The selected years for the analyses: 1992, 2002, 2012, and 2016, are close to the general election years and, in particular, 2002 and 2012 are the years when political regimes changed. ${ }^{3}$ In the analyses, the annual growth rates of the average nighttime luminosity index over grids surrounded by a county border are defined as the county's growth rates of nighttime light intensity and used as the dependent variable. Figure 8.1 shows the spatial distribution of nighttime light luminosity by grid in different time periods. Lighter yellow cells correspond to much brighter areas. The thresholds of color changes are set at $0,5,10,15, \ldots$, and 95 th percentile values of the 2012 nighttime luminosity data.

\subsubsection{Ethnic Groups and Settlement Patterns}

Kenya has more than forty ethnic groups. The largest ethnic group is Kikuyu and accounts for $17 \%$ of the total population, according to the Population and Housing Census of Kenya, conducted in 2009. It is followed by Luhya, Kalenjin, Luo, and Kamba, whose population shares are 14, 13, 12, and 10\%, respectively. The ethnic composition has been more or less stable since the independence of the country in 1963 (Burgess et al. 2015) and the settlement patterns have been maintained without any significant change, except in highly populated towns and cities. Figure 8.2 shows the spatial settlement patterns of major ethnic groups. ${ }^{4}$ We use the 1989 Population Census information on ethnic composition by district to construct ethnicity-related variables at the county level, namely, major ethnicity dummies, and the Herfindahl

\footnotetext{
${ }^{1}$ These data are downloaded from the following URL. https://ngdc.noaa.gov/eog/dmsp/ downloadV4composites.html.

${ }^{2}$ NASA Earth Observatory images by Joshua Stevens, using Suomi NPP VIIRS data from Miguel Román, NASA's Goddard Space Flight Center are downloaded from the following URL. https://www.nasa.gov/feature/goddard/2017/new-night-lights-maps-open-up-possiblereal-timeapplications.

${ }^{3}$ It was not in 2012 but in 2013 that the general election was held and selected President Uhuru Kenyatta. Since the nighttime luminosity data with high resolution are consistently available in 2012 and 2016 but not in 2013, we use the 2012 data, instead.

${ }^{4}$ The data source of the geo-referenced settlement patterns is the GeoEPR 2014 (Vogt et al. 2015).
} 


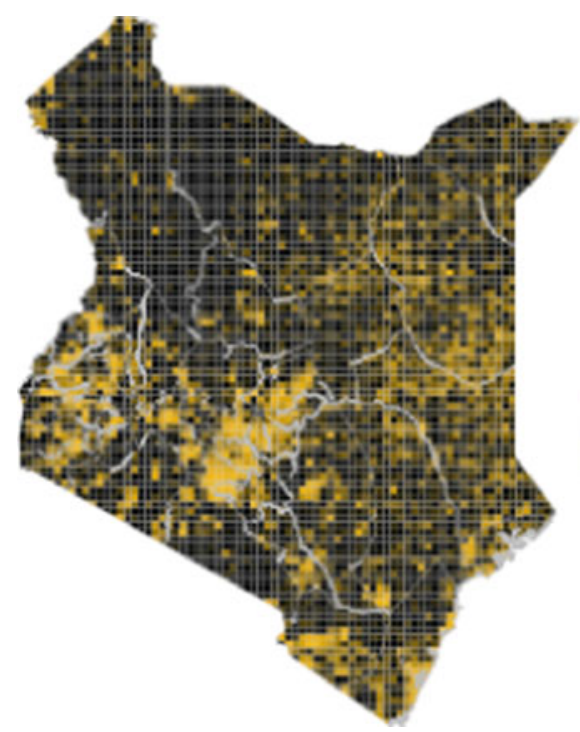

1992



2012

Fig. 8.1 Nighttime light intensity at grid level. Note Lighter yellow cells correspond to brighter areas at night. The thresholds of color changes are set at $0,5,10, \ldots$, and 95 percentile values at the grid level in the 2012 nighttime luminosity data

index of ethnic composition, indicating the degree of concentration of ethnicity in counties. $^{5}$

Five major ethnicity dummies, Kikuyu, Luhya, Kalenjin, Kamba, and Luo, are constructed, each of which takes the value of 1 if the corresponding ethnic group's population share in 1989 at the county level is more than $50 \%$ and 0 otherwise. There are 7 Kikuyu counties whose corresponding ethnicity dummy takes 1, 7 Kalenjin counties, 3 Kamba counties, 4 Luhya counties, and 4 Luo counties. There are 22 counties that do not have a dominant ethnic group or another minor ethnic group is dominant.

\subsubsection{Population Data}

We use Gridded Population of World (GPW) series to obtain the subnational level of population for the relevant years (GPWv3, GPWv4). Version 3 of GPW covers the population estimates at the grid

\footnotetext{
${ }^{5}$ There are 41 districts in the 1989 Population Census and 6 of them are subdivided, which correspond to the current 47 counties. We assign the same values of those ethnicity-related variables constructed from the 1989 census data to the counties that were a part of the subdivided former districts. In the analyses, we use ( 1 - Herfindahl index) as the measurement of ethnic diversity.
} 


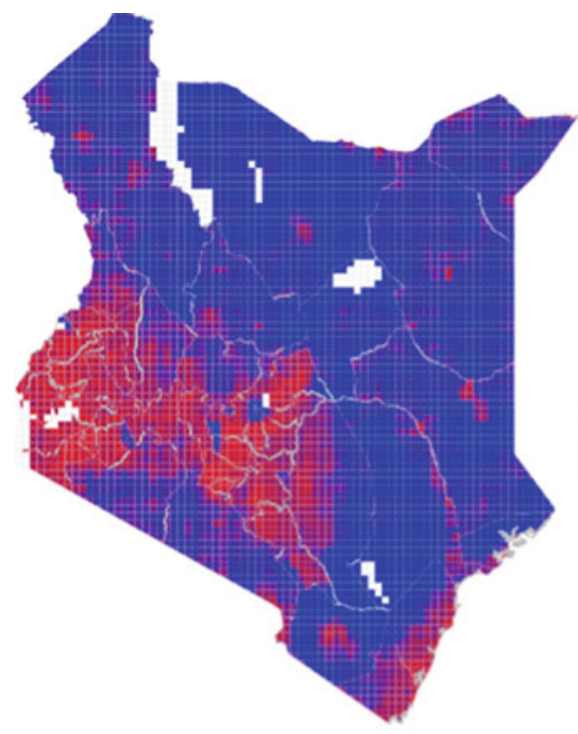

1990



2010

Fig. 8.2 Population density at grid level. Note Deeper red cells correspond to more populated areas. The thresholds of color changes are set at $0,10,20, \ldots$, and 90 percentile values at the grid level in the 2010 population data

cell resolution of 2.5 arc-minutes (about $5 \mathrm{~km}$ at equator) for the years 1990 , 1995 , and 2000, and version 4 covers those at the grid cell resolution of 30 arcseconds (about $1 \mathrm{~km}$ at equator) for the period after 2000, 2005, 2010, and 2015. Since we use the nighttime luminosity data in 1992, 2002, 2012, and 2016 and there is no population estimates for the corresponding years, we interpolate the population estimates for the relevant years by assuming constant growth rates between the 5-year periods for which the GPW estimates are available. We use this data to control for the population size of counties in the regressions. Figure 8.3 shows the spatial distribution of population over grid cells. Deeper red cells correspond to more populated areas. The thresholds of color changes are at $0,10,20, \ldots$, and 90th percentile values of the 2015 population data.

\subsubsection{Characteristics of Governors and Residents of Counties}

The governors elected in the general election in 2013 under the devolved government have had greater authority on use of public funds for county residents than local leaders in the past. It is interesting to see the association between the governors' characteristics and the growth rates of counties. We collected, online, the attributes 


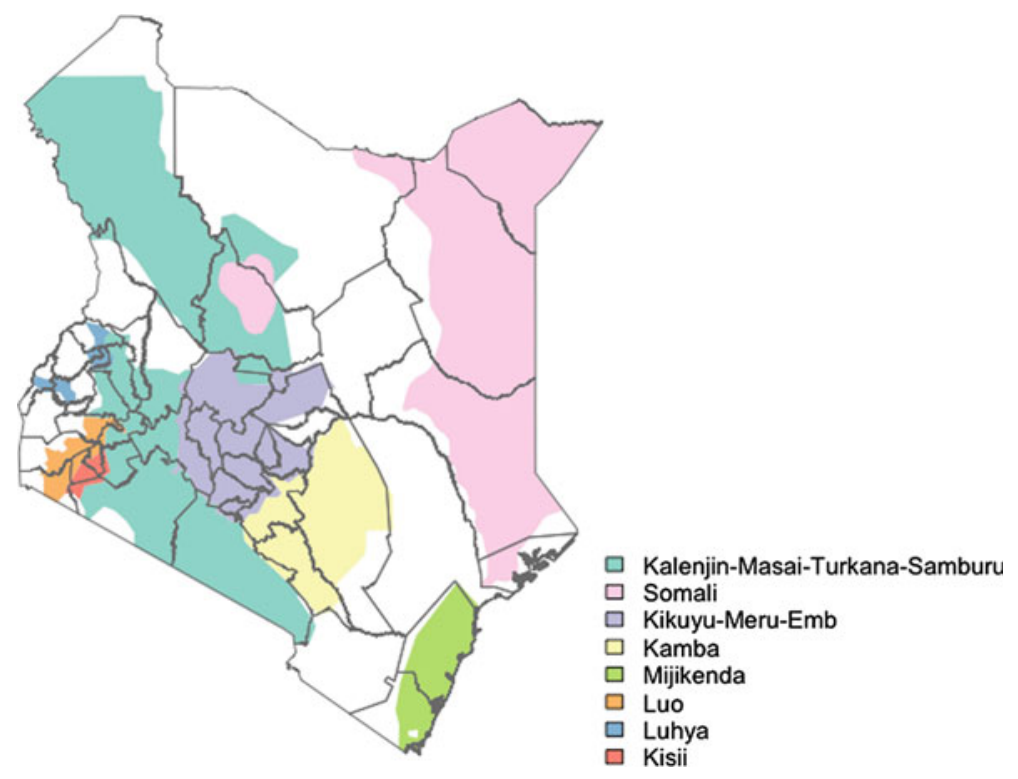

Fig. 8.3 Spatial settlement patterns of ethnic groups

of the elected governors in 2013, such as age, number of years of experience as a Member of Parliament (MP), whether the governor was born and brought up in the same county, whether he/she is M.A. or Ph.D. holder, whether he/she studied abroad, rates of votes obtained in the election, political party, and coalition to which the party belongs.

In addition to the governors' attributes, under the decentralized democracy, local residents' voices may have a stronger influence on the usage of public resources than those under the centralized system. Thus, there is a possibility that the human capital of the county could affect the usage of public resources and, hence, regional development. We use proportion of secondary school, tertiary school, or university graduates among adult residents in a county as its human capital indicator. This information on educational attainment of county residents is taken from the Population and Housing Census of 2009.

\subsection{Empirical Specification}

In order to examine factors affecting the economic growth rates at the subnational level, we run simple growth regressions of nighttime light intensity, as follows:

$$
G R_{i, t} \equiv \frac{\ln y_{i, t+\tau}-\ln y_{i, t}}{\tau}=\alpha \ln y_{i, t}+x_{i, t}^{\prime} \beta+\varepsilon_{i, t},
$$


where $G R_{i, t}$ is the average annual growth rate of nighttime light intensity (NLI) at the $i$-th county from year $t$ to $t+\tau$, which is calculated as the difference in natural $\log$ of nighttime light intensity indicator $y_{i}$ between year $t$ and $t+\tau$ divided by $\tau$. As explanatory variables, we use the natural log of $y$ at the initial period, whose coefficient $\alpha$ is expected to take a negative value if there is convergence in the nighttime light intensity across counties or, in other words, if brighter counties at night show lower growth rate of nighttime light intensity; $x_{i, t}$ is a column vector of county characteristics, including a series of the major ethnicity dummies, one minus the Herfindahl index of ethnic composition (indicating a measurement of ethnic diversity), whether the county is the president's home county, size of population, human capital indicators of county residents, and governors' ages, educational attainment, and years of experience as an MP. ${ }^{6}$

\subsection{Results}

\subsubsection{Growth of Nighttime Light Intensity and Ethnicity}

Table 8.2 presents the regression results of average annual growth rates of nighttime light intensity of 47 counties on 5 major ethnicity dummies in order to examine the difference in the growth rates across counties with specific major ethnic groups. Among 47 counties, there are 7 Kikuyu, 7 Kalenjin, 3 Kamba, 4 Luhya, and 4 Luo dominant counties. The other 22 counties, where there is no single ethnic group whose share is more than $50 \%$, are considered as the reference group in the regression. Column 1 shows the regression result using the average growth rates of the entire sample period (1992-2016) as the dependent variable. It suggests that the average annual growth rates of Kikuyu dominant counties are higher by 1.4 percentage points than the other 22 counties, which do not have a dominant ethnic group, while those of counties with another major ethnic group show insignificant difference.

Column 2 presents the results of the same regression using the limited sample period corresponding to President Moi's era under the multiparty system (December 1992-December 2002). There seem to be no major ethnicity dummies that are significantly associated with the growth rates. Similarly, Column 3 presents the results using the sample period largely overlapping with President Kibaki's era (December 2002-April 2013) and shows no significant effects of ethnicity dummies either. The coefficient of the constant term indicates the average annual growth rate of nighttime light intensity in the reference group, comprising the 22 counties with no dominant ethnic group, and shows low (or almost zero) growth rate in the Moi period (Column 2) and high (or about 5\%) annual growth rate in the Kibaki period (Column 3), which is consistent with the national level GDP trend between the eras of these two pres-

\footnotetext{
${ }^{6}$ We also used the governor's political affiliation, the rate of votes obtained in the election, a dummy indicating whether he/she was originally from the county or not as covariates in the regression analyses. But none of them are statistically significant.
} 
Table 8.2 Average annual growth rate of nighttime light intensity and major ethnicity of county

\begin{tabular}{|c|c|c|c|c|}
\hline \multirow[t]{3}{*}{ Variables } & (1) & (2) & (3) & (4) \\
\hline & $\begin{array}{l}\text { Whole sample } \\
\text { period }\end{array}$ & $\begin{array}{l}\text { Moi (Kalenjin) } \\
\text { period }\end{array}$ & $\begin{array}{l}\text { Kibaki } \\
\text { (Kikuyu) period }\end{array}$ & $\begin{array}{l}\text { Kenyatta } \\
\text { (Kikuyu) period }\end{array}$ \\
\hline & 1992-2016 & $1992-2002$ & $2002-2012$ & $2012-2016$ \\
\hline \multirow[t]{2}{*}{1 if Kikuyu county [7] } & $0.0140 * *$ & 0.00261 & 0.0165 & $0.0361 * * *$ \\
\hline & $(0.00640)$ & $(0.0195)$ & $(0.0141)$ & $(0.00951)$ \\
\hline \multirow[t]{2}{*}{1 if Kalenjin county [7] } & 0.00854 & 0.0253 & -0.00482 & $-2.94 \mathrm{e}-05$ \\
\hline & $(0.00640)$ & $(0.0195)$ & $(0.0141)$ & $(0.00951)$ \\
\hline \multirow[t]{2}{*}{1 if Kamba county [3] } & 0.0136 & 0.00969 & 0.0218 & 0.00315 \\
\hline & $(0.00907)$ & $(0.0277)$ & $(0.0200)$ & $(0.0135)$ \\
\hline \multirow[t]{2}{*}{1 if Luhya county [4] } & 0.00254 & 0.0222 & -0.0134 & -0.00669 \\
\hline & $(0.00801)$ & $(0.0245)$ & $(0.0177)$ & $(0.0119)$ \\
\hline \multirow[t]{2}{*}{1 if Luo county [4] } & -0.00730 & -0.0113 & -0.00869 & 0.00617 \\
\hline & $(0.00801)$ & $(0.0245)$ & $(0.0177)$ & $(0.0119)$ \\
\hline \multirow[t]{2}{*}{ Constant } & $0.0266 * * *$ & 0.00807 & $0.0517 * * *$ & $0.0101 * *$ \\
\hline & $(0.00314)$ & $(0.00960)$ & $(0.00693)$ & $(0.00467)$ \\
\hline Observations & 47 & 47 & 47 & 47 \\
\hline R-squared & 0.182 & 0.065 & 0.093 & 0.29 \\
\hline
\end{tabular}

Standard errors in parentheses. $* * * p<0.01, * * p<0.05, * p<0.1$

Coefficients are obtained by running simple OLS of the average annual growth rate of nighttime light intensity at county level on a set of major ethnicity dummies. A major ethnicity dummy (Kikuyu, Kalenjin, Kamba, Luhya, or Luo) takes 1 if the corresponding ethnic group's population share in 1989 at the county is more than $50 \%$ and 0 otherwise. Numbers in brackets indicate the number of counties which take 1 for the corresponding major ethnicity dummy

idents. Column 4 presents the result using the sample period that largely overlaps with President Uhuru Kenyatta's era and shows significantly higher average growth rates in Kikuyu dominant counties by 3.6 percentage points than those in reference group counties, which have no dominant ethnic groups. To summarize, there is no systematic correlation between the growth rate of nighttime light intensity and major ethnicity of counties until 2012, while Kikuyu dominant counties show higher growth rates since then. It is well-known that President Kenyatta (April 2013-) is from one of the Kikuyu dominant counties, namely, Kiambu and served as the Member of Parliament for the Gatundu South constituency in the county from 2002 to 2013, until he became the President.

Table 8.3 shows the results of the regressions, like those given in Table 8.1, with some additional controls. The initial level of the nighttime light intensity is controlled for and the presidents' home county dummies are included. The results reconfirm that there is no correlation between the growth rate and ethnicity until 2012, while Kikuyu dominant counties show higher growth rates since 2012. Interestingly, Kiambu county, which is the home county of President Uhuru Kenyatta shows the 
highest annual average growth rate of nighttime light intensity from 2012 to 2016, among all the 47 counties. In addition, the coefficient of the natural log of the NLI in the initial period is positive and significant in this period (2012-2016), which indicates divergence rather than convergence in the nighttime light intensity across counties or, in other words, higher growth rate in the counties where the initial level of the nighttime light intensity is higher. This suggests that the inequality across counties may increase during the period.

We add two more explanatory variables, a measurement of ethnic diversity of counties and the natural log of population size of counties during the initial period in the regressions in Table 8.4. The coefficient estimates of the major ethnicity dummies and the home county dummies of presidents are similar to those in the previous regressions that excluded the two variables. The initial population size is positively associated with NLI growth in the latest 5-year period. Populated counties became brighter than less populated counties in this period. This finding also suggests the divergence in nighttime light intensity and escalation of inequality across counties under the process of devolution. The coefficient estimate of the measurement of ethnic diversity of counties is positive and significant in the regression of the NLI growth during the Moi period (1992-2002), indicating that higher growth rate of the nighttime light intensity during this period is observed in more ethnically diversified counties. As comprehensively reviewed in Alesina and La Ferrara (2005), ethnic diversity can have both positive and negative effects on the economic performance of societies. On the one hand, ethnic diversity can bring about a variety of ideas, abilities, experiences, and cultures, which can be a source of innovation and creativity and lead to higher economic performance. On the other hand, it can make collective actions among residents difficult due to differences in preferences, leading to high costs of provision and maintenance of public goods, and can also create tension between ethnic groups due to conflict of interests and lower economic performance. Although it seems interesting to explore the reason for the positive coefficient of the ethnic diversity index on NLI growth during President Moi's period, further investigation is required for the identification of factors.

\subsubsection{Growth of Nighttime Light Intensity Under the New Constitution}

The new constitution, promulgated in 2010, established a system of a devolved government with 47 lower-level county governments and, subsequently, new county governors were elected in 2013 who were responsible for the county's governance and development. Expecting stronger influence of local governments and residents on local economic development after the dramatic political system change in Kenya, we examine county-level factors associated with the growth of nighttime light intensity. For this period, some additional information, such as the proportion of urban residents, and several indicators of the educational level of county residents, namely, proportions of university graduates, residents with tertiary level education, and resi- 
Table 8.3 Average annual growth rate of nighttime light intensity (NLI) and major ethnicity of county

\begin{tabular}{|c|c|c|c|c|}
\hline \multirow[t]{3}{*}{ Variables } & (1) & (2) & (3) & (4) \\
\hline & $\begin{array}{l}\text { Whole sample } \\
\text { period }\end{array}$ & $\begin{array}{l}\text { Moi (Kalenjin) } \\
\text { period }\end{array}$ & $\begin{array}{l}\text { Kibaki } \\
\text { (Kikuyu) period }\end{array}$ & $\begin{array}{l}\text { Kenyatta } \\
\text { (Kikuyu) period }\end{array}$ \\
\hline & $1992-2016$ & 1992-2002 & 2002-2012 & 2012-2016 \\
\hline \multirow{2}{*}{$\begin{array}{l}\ln (\mathrm{NLI} \text { in the initial } \\
\text { year) }\end{array}$} & -0.00182 & -0.00855 & -0.00881 & $0.00669 * *$ \\
\hline & $(0.00260)$ & $(0.00786)$ & (0.00539) & $(0.00278)$ \\
\hline \multirow[t]{2}{*}{1 if Kikuyu county } & 0.0115 & 0.00584 & 0.00969 & $0.0210 * *$ \\
\hline & $(0.00766)$ & $(0.0232)$ & $(0.0163)$ & $(0.00814)$ \\
\hline \multirow[t]{2}{*}{1 if Kalenjin county } & 0.00704 & 0.0162 & -0.0133 & 0.00822 \\
\hline & $(0.00773)$ & $(0.0234)$ & $(0.0160)$ & $(0.00805)$ \\
\hline \multirow[t]{2}{*}{1 if Kamba county } & 0.0133 & 0.00794 & 0.0208 & 0.00241 \\
\hline & $(0.00946)$ & $(0.0286)$ & $(0.0202)$ & $(0.0101)$ \\
\hline \multirow[t]{2}{*}{1 if Luhya county } & $5.68 \mathrm{e}-05$ & 0.0105 & -0.0235 & 0.00185 \\
\hline & (0.00906) & $(0.0274)$ & $(0.0189)$ & $(0.00960)$ \\
\hline \multirow[t]{2}{*}{1 if Luo county } & -0.00897 & -0.0191 & -0.0178 & 0.0136 \\
\hline & $(0.00867)$ & $(0.0262)$ & (0.0187) & $(0.00944)$ \\
\hline \multirow{2}{*}{$\begin{array}{l}1 \text { if Balingo (Moi's } \\
\text { home county) }\end{array}$} & -0.00424 & -0.00542 & 0.00350 & -0.0130 \\
\hline & $(0.0166)$ & $(0.0502)$ & $(0.0355)$ & $(0.0177)$ \\
\hline \multirow{2}{*}{$\begin{array}{l}1 \text { if Nyeri (Kibaki's } \\
\text { home county) }\end{array}$} & 0.00437 & -0.0199 & 0.0257 & 0.0130 \\
\hline & $(0.0168)$ & $(0.0509)$ & $(0.0360)$ & $(0.0180)$ \\
\hline \multirow{2}{*}{$\begin{array}{l}1 \text { if Kiambu } \\
\text { (Kenyatta's home } \\
\text { county) }\end{array}$} & 0.0123 & -0.00622 & 0.0198 & $0.0865 * * *$ \\
\hline & $(0.0176)$ & $(0.0532)$ & $(0.0372)$ & $(0.0186)$ \\
\hline \multirow[t]{2}{*}{ Constant } & $0.0402 * *$ & 0.0724 & $0.119 * * *$ & $-0.0441^{*}$ \\
\hline & (0.0198) & $(0.0599)$ & $(0.0415)$ & $(0.0228)$ \\
\hline Observations & 47 & 47 & 47 & 47 \\
\hline R-squared & 0.201 & 0.102 & 0.165 & 0.641 \\
\hline
\end{tabular}

Standard errors in parentheses. $* * * p<0.01, * * p<0.05, * p<0.1$

Coefficients are obtained by running simple OLS of the average annual growth rate of nighttime light intensity at county level on the log of the initial level of the NLI level, a set of major ethnicity dummies and the president's home county dummies. A major ethnicity dummy (Kikuyu, Kalenjin, Kamba, Luhya, or Luo) takes 1 if the corresponding ethnic group's population share in 1989 at the county is more than $50 \%$ and 0 otherwise 
Table 8.4 Average annual growth rate of nighttime light intensity (NLI) and major ethnicity of county

\begin{tabular}{|c|c|c|c|c|}
\hline \multirow[t]{3}{*}{ Variables } & (1) & (2) & (3) & (4) \\
\hline & $\begin{array}{l}\text { Whole sample } \\
\text { period }\end{array}$ & $\begin{array}{l}\text { Moi (Kalenjin) } \\
\text { period }\end{array}$ & $\begin{array}{l}\text { Kibaki } \\
\text { (Kikuyu) } \\
\text { period }\end{array}$ & $\begin{array}{l}\text { Kenyatta } \\
\text { (Kikuyu) } \\
\text { period }\end{array}$ \\
\hline & $1992-2016$ & 1992-2002 & $2002-2012$ & $2012-2016$ \\
\hline \multirow[t]{2}{*}{$\ln$ (NLI in the initial year) } & -0.00312 & $-0.0136^{*}$ & -0.00623 & 0.00289 \\
\hline & $(0.00268)$ & $(0.00780)$ & $(0.00598)$ & $(0.00279)$ \\
\hline \multirow[t]{2}{*}{1 if Kikuyu county } & 0.00817 & -0.00434 & 0.0120 & $0.0167 * *$ \\
\hline & $(0.00784)$ & $(0.0229)$ & $(0.0168)$ & $(0.00751)$ \\
\hline \multirow[t]{2}{*}{1 if Kalenjin county } & 0.00291 & -0.00266 & -0.00543 & 0.000449 \\
\hline & $(0.00809)$ & $(0.0236)$ & $(0.0172)$ & $(0.00784)$ \\
\hline \multirow[t]{2}{*}{1 if Kamba county } & 0.0108 & 0.0101 & 0.0147 & -0.00137 \\
\hline & $(0.0101)$ & $(0.0293)$ & $(0.0214)$ & $(0.00951)$ \\
\hline \multirow[t]{2}{*}{1 if Luhya county } & -0.00495 & -0.00139 & -0.0224 & -0.00895 \\
\hline & $(0.00963)$ & $(0.0281)$ & $(0.0204)$ & $(0.00938)$ \\
\hline \multirow[t]{2}{*}{1 if Luo county } & -0.0128 & -0.0242 & -0.0195 & 0.00451 \\
\hline & $(0.00928)$ & $(0.0270)$ & $(0.0202)$ & $(0.00916)$ \\
\hline \multirow{2}{*}{$\begin{array}{l}1 \text { if Balingo (Moi's home } \\
\text { county) }\end{array}$} & -0.000278 & 0.0133 & -0.00437 & -0.00671 \\
\hline & $(0.0166)$ & $(0.0484)$ & $(0.0360)$ & $(0.0163)$ \\
\hline \multirow{2}{*}{$\begin{array}{l}1 \text { if Nyeri (Kibaki's home } \\
\text { county) }\end{array}$} & 0.00842 & 0.00453 & 0.0139 & 0.0198 \\
\hline & $(0.0170)$ & $(0.0496)$ & $(0.0368)$ & $(0.0167)$ \\
\hline \multirow{2}{*}{$\begin{array}{l}1 \text { if Kiambu (Kenyatta's } \\
\text { home county) }\end{array}$} & 0.0136 & 0.0143 & 0.00436 & $0.0880 * * *$ \\
\hline & $(0.0180)$ & $(0.0525)$ & $(0.0387)$ & $(0.0174)$ \\
\hline \multirow{2}{*}{$\begin{array}{l}\text { Ethnic diversity (1 - } \\
\text { Herfindahl index) }\end{array}$} & 0.0132 & $0.0756 * *$ & -0.0369 & 0.0164 \\
\hline & $(0.0114)$ & $(0.0332)$ & $(0.0257)$ & $(0.0112)$ \\
\hline \multirow{2}{*}{$\begin{array}{l}\ln \text { (population in the initial } \\
\text { year) }\end{array}$} & 0.00435 & 0.00632 & 0.00317 & $0.0107 * * *$ \\
\hline & $(0.00394)$ & $(0.0115)$ & $(0.00864)$ & $(0.00393)$ \\
\hline \multirow[t]{2}{*}{ Constant } & -0.00940 & 0.00770 & 0.0684 & $-0.162 * * *$ \\
\hline & $(0.0506)$ & (0.148) & (0.110) & $(0.0495)$ \\
\hline Observations & 47 & 47 & 47 & 47 \\
\hline R-squared & 0.263 & 0.232 & 0.212 & 0.721 \\
\hline
\end{tabular}

Standard errors in parentheses. $* * * p<0.01, * * p<0.05, * p<0.1$

Coefficients are obtained by running simple OLS of the average annual growth rate of nighttime light intensity at county level on the log of the initial level of the NLI level, a set of major ethnicity dummies and the president's home county dummies. A major ethnicity dummy (Kikuyu, Kalenjin, Kamba, Luhya, or Luo) takes 1 if the corresponding ethnic group's population share in 1989 at the county is more than $50 \%$ and 0 otherwise 
dents with secondary level education, were taken from the Census in 2009, conducted by the Kenya National Bureau of Statistics.

Table 8.5 shows the results of the regressions of the NLI growth from 2012 to 2016 on the county-level factors. We reconfirm that there is no sign of convergence of nighttime light intensity across counties during this period in the regressions with the additional controls. If there is a sign of convergence, the coefficient of initial level of nighttime intensity should be negative. The coefficient in Column 1, however, is positive and significant. Although the coefficients are insignificant in Columns $2-4$, controls that are highly and positively correlated with nighttime light intensity at the initial level, such as proportion of urban residents in 2009, are included in the regressions. Moreover, the proportion of urban residents in 2009 is positively associated with the growth rate of nighttime light intensity between 2012 and 2016. These results imply that brighter counties at night in the initial year (or 2012) became even much brighter over the years.

The variables representing residents' average educational level above secondary school are all positive and significant, indicating strong positive correlation between conventional human capital indicators and economic development of counties. Although this finding is interesting, these simple regressions do not reveal the mechanism. There seem to be many different scenarios, which can account for the positive correlation. For instance, as often shown in studies of cross-country growth regression, human capital can be an important source of innovation and, hence, high economic growth can be realized in places with educated residents. It is also possible that residents' education may be a good proxy of competence or capacity of local government officers and those in areas with more educated residents may be able to implement government projects more successfully and use public resources more efficiently, which may lead to higher economic growth. Alternatively, educated residents may show different preferences for usage of public resources and have significant influence under a decentralized political system, which indirectly affects the economic performance of the areas. Further investigation is necessary to identify the mechanism behind this.

Table 8.6 shows the results of similar regressions with additional controls on the ethnic diversity indicator, the natural log of population size during the initial period (2012), and the governors' characteristics. The coefficients of the variables used in the previous regressions, presented in Table 8.5, have the same signs and suggest the robustness of the correlations of those variables with the NLI growth, although some of them change their statistical significance slightly. The changes in the significance levels are possibly due to multicollinearity of the initial population size with the educational variables, since they are strongly and positively correlated. In terms of the coefficients of the newly added governors' attributes, none of them are statistically significant, although we expected that governors' leadership, motivation, and capability would influence the economic performance of counties under the decentralized system. This may reflect the inability of the governors' attributes, used in these analyses, to capture their leadership, motivation, and capability or may indicate very weak influence of the governors on local development, even under the new constitution. 
Table 8.5 Average annual growth rate of nighttime light intensity from 2012 to 2016

\begin{tabular}{|c|c|c|c|c|}
\hline \multirow[t]{2}{*}{ Variables } & (1) & (2) & (3) & (4) \\
\hline & Model 1 & Model 2 & Model 3 & Model 4 \\
\hline \multirow[t]{2}{*}{$\ln (\mathrm{NLI}$ in 2012) } & $0.00525^{* *}$ & -0.000568 & $9.61 \mathrm{e}-05$ & 0.00280 \\
\hline & $(0.00233)$ & $(0.00194)$ & $(0.00197)$ & $(0.00217)$ \\
\hline \multirow[t]{2}{*}{1 if Kikuyu county } & $0.0208 * * *$ & $0.0216^{* * * *}$ & $0.0198 * * *$ & $0.0135^{* *}$ \\
\hline & $(0.00700)$ & $(0.00509)$ & $(0.00527)$ & $(0.00580)$ \\
\hline \multirow{2}{*}{$\begin{array}{l}1 \text { if Kiambu (Kenyatta's } \\
\text { home county) }\end{array}$} & $0.0868 * * *$ & $0.0740 * * *$ & $0.0705 * * *$ & $0.0715^{* * *}$ \\
\hline & $(0.0177)$ & $(0.0129)$ & $(0.0131)$ & $(0.0125)$ \\
\hline \multirow{2}{*}{$\begin{array}{l}\text { Proportion of urban } \\
\text { residents }\end{array}$} & & $0.0333 * *$ & 0.0297* & 0.0229 \\
\hline & & $(0.0146)$ & $(0.0161)$ & $(0.0153)$ \\
\hline \multirow{2}{*}{$\begin{array}{l}\text { Proportion of university } \\
\text { graduates }\end{array}$} & & $0.613 * *$ & & \\
\hline & & $(0.251)$ & & \\
\hline \multirow{2}{*}{$\begin{array}{l}\text { Proportion of residents } \\
\text { with tertiary level } \\
\text { education }\end{array}$} & & & $0.253 * *$ & \\
\hline & & & $(0.107)$ & \\
\hline \multirow{2}{*}{$\begin{array}{l}\text { Proportion of residents } \\
\text { with secondary level } \\
\text { education }\end{array}$} & & & & $0.0904 * * *$ \\
\hline & & & & $(0.0295)$ \\
\hline \multirow[t]{2}{*}{ Constant } & -0.0302 & 0.000747 & -0.00638 & $-0.0326^{*}$ \\
\hline & $(0.0181)$ & $(0.0140)$ & $(0.0143)$ & $(0.0172)$ \\
\hline Observations & 47 & 47 & 47 & 47 \\
\hline R-squared & 0.608 & 0.806 & 0.804 & 0.819 \\
\hline
\end{tabular}

Standard errors in parentheses. $* * * p<0.01, * * p<0.05, * p<0.1$

Proportions of urban residents, university graduates, residents with tertiary level education, residents with secondary level education are constructed based on Census in 2009

\subsection{Conclusions}

Kenya has experienced a significant change in its political system from a highly centralized autocracy to decentralized democracy during the last twenty years. This chapter examines local economic development and its determinants during the period of devolution. Using satellite images of nighttime light intensity as a measurement of subnational economic performance, we investigate factors affecting the economic development in Kenya from 1992 to 2016.

First, we find that there is no systematic relationship between major ethnicity of counties and their growth rates of nighttime light intensity until 2012. This seems consistent with the finding from the analysis of public resource allocation from 1963 
Table 8.6 Average annual growth rate of nighttime light intensity from 2012 to 2016

\begin{tabular}{|c|c|c|c|c|}
\hline \multirow[t]{2}{*}{ Variables } & $(1)$ & (2) & (3) & (4) \\
\hline & Model 1 & Model 2 & Model 3 & Model 4 \\
\hline \multirow[t]{2}{*}{$\ln (\mathrm{NLI}$ in 2012) } & 0.00390 & -0.000799 & -0.000365 & 0.00171 \\
\hline & $(0.00239)$ & $(0.00205)$ & $(0.00205)$ & $(0.00230)$ \\
\hline \multirow[t]{2}{*}{1 if Kikuyu county } & $0.0198 * * *$ & $0.0214 * * *$ & $0.0197 * * *$ & $0.0148 * *$ \\
\hline & $(0.00673)$ & $(0.00521)$ & $(0.00534)$ & $(0.00610)$ \\
\hline \multirow{2}{*}{$\begin{array}{l}1 \text { if Kiambu (Kenyatta's } \\
\text { home county) }\end{array}$} & $0.0859 * * *$ & $0.0688 * * *$ & $0.0666 * * *$ & $0.0684 * * *$ \\
\hline & $(0.0173)$ & $(0.0138)$ & $(0.0139)$ & $(0.0135)$ \\
\hline \multirow[t]{2}{*}{ Proportion of urban residents } & & $0.0410 * *$ & $0.0374 * *$ & $0.0315^{*}$ \\
\hline & & $(0.0152)$ & $(0.0165)$ & $(0.0167)$ \\
\hline \multirow{2}{*}{$\begin{array}{l}\text { Proportion of university } \\
\text { graduates }\end{array}$} & & 0.465 & & \\
\hline & & $(0.286)$ & & \\
\hline \multirow{2}{*}{$\begin{array}{l}\text { Proportion of residents with } \\
\text { tertiary level education }\end{array}$} & & & 0.200 & \\
\hline & & & $(0.120)$ & \\
\hline \multirow{2}{*}{$\begin{array}{l}\text { Proportion of residents with } \\
\text { secondary level education }\end{array}$} & & & & $0.0736^{* *}$ \\
\hline & & & & $(0.0355)$ \\
\hline \multirow{2}{*}{$\begin{array}{l}\text { Ethnic diversity (1 - } \\
\text { Herfindahl Index) }\end{array}$} & 0.0125 & -0.0103 & -0.0104 & -0.00961 \\
\hline & $(0.0103)$ & $(0.00909)$ & $(0.00908)$ & $(0.00874)$ \\
\hline \multirow[t]{2}{*}{ In (population in 2012) } & $0.0102 * * *$ & $0.00547 *$ & $0.00585^{*}$ & 0.00503 \\
\hline & $(0.00372)$ & $(0.00314)$ & $(0.00305)$ & $(0.00307)$ \\
\hline \multirow{2}{*}{$\begin{array}{l}\text { Years of experience of the } \\
\text { county governor as a MP }\end{array}$} & -0.000415 & -0.000114 & -0.000220 & -0.000255 \\
\hline & $(0.000718)$ & $(0.000561)$ & $(0.000554)$ & $(0.000543)$ \\
\hline \multirow[t]{2}{*}{ Age of the county governor } & 0.000142 & $8.69 \mathrm{e}-05$ & $7.15 \mathrm{e}-05$ & $1.72 \mathrm{e}-07$ \\
\hline & $(0.000283)$ & $(0.000223)$ & $(0.000225)$ & $(0.000227)$ \\
\hline \multirow{2}{*}{$\begin{array}{l}1 \text { if the county governor has } \\
\text { Ph.D. }\end{array}$} & 0.00136 & -0.000420 & -0.00120 & -0.00113 \\
\hline & $(0.00671)$ & $(0.00522)$ & $(0.00519)$ & $(0.00509)$ \\
\hline \multirow[t]{2}{*}{ Constant } & $-0.169 * * *$ & -0.0732 & $-0.0822 *$ & $-0.0884 * *$ \\
\hline & $(0.0488)$ & $(0.0440)$ & $(0.0418)$ & $(0.0397)$ \\
\hline Observations & 47 & 47 & 47 & 47 \\
\hline R-squared & 0.700 & 0.831 & 0.832 & 0.838 \\
\hline
\end{tabular}

Standard errors in parentheses. $* * * p<0.01, * * p<0.05, * p<0.1$

Proportions of urban residents, university graduates, residents with tertiary level education, residents with secondary level education are constructed based on Census in 2009 
to 2011 in Kenya by Burgess et al. (2015), which argues that ethnic favoritism disappears after the country has embraced a multiparty democratic system. The second finding of this paper, however, shows a somewhat different scenario during the latest five-year period (2012-2016) that overlaps with the ruling period of President Uhuru Kenyatta (whose ethnicity is Kikuyu). Kikuyu counties show much higher growth rates than other counties, and moreover Kiambu county, which is the home county of the president, shows the highest growth rate among 47 counties. We do not claim that this is the evidence of revival of ethnic favoritism, since the result shows only correlation rather than causation, and there are many possible confounding factors that create spurious correlation between ethnicity and economic performance.

Third, personal characteristics of county governors, such as their educational attainment and past experiences as an MP, are not associated with the growth rate. Fourth, human capital indicators of the counties, measured by proportions of secondary school graduates or university graduates, are positively associated with the growth rate of nighttime light intensity in recent periods.

This study simply shows empirical findings regarding factors associated with subnational economic growth by examining, as a case study, an emerging country in Africa that has experienced high economic growth and a significant change in its political system over the last two decades. Although the findings seem interesting, it does not analyze the mechanisms behind the results, which remains for future research.

\section{References}

Alesina A, Michalopoulos S, Papaioannou E (2016) Ethnic inequality. J Polit Econ 124(2):428-488 Alesina A, La Ferrara E (2005) Ethnic diversity and economic performance. J Econ Lit 43(3):762-800

Amavilah VH (2017) Artificial nighttime lights and the "real" well-being of nations: "measuring economic growth from outer space' and welfare from right here on Earth. MPRA Paper 79744, University Library of Munich, Germany, June 2017

Asher S, Novosad P (2017) Politics and local economic growth: evidence from India. Am Econ J: Appl Econ 9(1):229-273

Auya S, Oino P (2013) The role of constituency development fund in rural development: experiences from North Mugirango constituency, Kenya. Int J Sci Res 2(6):306-312

Bahl RW, Ichimura S (2008) Decentralization policies in Asian development. World Scientific, Singapore

Briggs RC (2014) Aiding and abetting: project aid and ethnic politics in Kenya. World Dev 64:194-205

Burgess R, Jedwab R, Miguel E, Morjaria A (2015) The value of democracy: evidence from road building in Kenya. Am Econ Rev 105(6):1817-1851

Center for International Earth Science Information Network CIESIN Columbia University and Centro Internacional de Agricultura Tropical CIAT (2005) Gridded population of the world, version 3 (GPWV3): population density grid. http://dx.doi.org/10.7927/H4ST7MRB. Accessed 25 May 2017

Center for International Earth Science Information Network CIESIN Columbia University and Centro Internacional de Agricultura Tropical CIAT (2016) Gridded population of the world, 
version 4 (GPWV4): population density grid. https://doi.org/10.7927/H4X63JVC. Accessed 2 June 2017

Chen X, Nordhaus WD (2011) Using luminosity data as a proxy for economic statistics. Proc Natl Acad Sci 108(21):8589-8594

Doll CNH, Muller JP, Morley JG (2006) Mapping regional economic activity from nighttime light satellite imagery. Ecol Econ 57(1):75-92

Easterly W (2008) Institutions: top down or bottom up? MPRA Paper 39137, University Library of Munich, Germany, May 2008

Henderson JV, Storeygard A, Weil DN (2012) Measuring economic growth from outer space. Am Econ Rev 102(2):994-1028

Hodler R, Raschky PA (2014) Regional favoritism. Quart J Econ 129(2):995-1033

Jerven M (2013) Poor numbers: how we are misled by African development statistics and what to do about it. Cornell University Press, Ithaca

Katamei JM, Omwono GA Sr, Wanza L (2015) Challenges of strategy implementation on performance of constituency development fund projects in Kenya: a case of Marakwet west constituency. Int J Bus Adm 6(3):48-62

Kimenyi MS (2005) Efficiency and efficacy of Kenya's constituency development fund: theory and evidence. Economics Working Papers

Mellander C, Jose L, Stolarick K, Matheson Z (2015) Night-time light data: a good proxy measure for economic activity? PLoS ONE 10(10):e0139779. https://doi.org/10.1371/journal.pone.0139779

Ngiri DM, Nyaribo WM (2016) Effect of constituency development fund on socio-economic development in Mbeere South constituency, Kenya. Int J Econ Finance Manag Sci 4(4):182-189

Simiyu RS, Mweru JN, Omete FI (2014) The effects of decentralized funding on socio-economic welfare of Kenyans: a case study of the constituency development fund in Kimilili (Kenya). Eur J Acc Auditing Finance Res 2(7):31-51

Vogt M, Bormann NC, Rüegger S, Cederman LE, Hunziker P, Girardin L (2015) Integrating data on ethnicity, geography, and conflict: the ethnic power relations data set family. J Conflict Resolut 59(7):1327-1342

Open Access This chapter is licensed under the terms of the Creative Commons AttributionNonCommercial-NoDerivatives 4.0 International License (http://creativecommons.org/licenses/bync-nd/4.0/), which permits any noncommercial use, sharing, distribution and reproduction in any medium or format, as long as you give appropriate credit to the original author(s) and the source, provide a link to the Creative Commons license and indicate if you modified the licensed material. You do not have permission under this license to share adapted material derived from this chapter or parts of it.

The images or other third party material in this chapter are included in the chapter's Creative Commons license, unless indicated otherwise in a credit line to the material. If material is not included in the chapter's Creative Commons license and your intended use is not permitted by statutory regulation or exceeds the permitted use, you will need to obtain permission directly from the copyright holder.

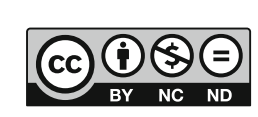

